\title{
International symposium on Precambrian accretionary orogens and Field workshop in the Dharwar craton, India
}

\author{
2 - 11 February 2011, New Delhi, India
}

In recent years the concept of orogens was used to discuss the origin and tectonic history of continents. Precambrian accretionary orogens contribute large scale continental growth and contain enormous mineral wealth. During the last two decades projects in solid earth sciences have generated comprehensive knowledge base on the Precambrian continental fragments in Canada, southern Africa and Australia. The peninsular India comprises collage of Archaean cratons (Dharwar, Bastar, Singhbhum, Aravalli and Bundelkhand) which are bounded by mobile belts. Although the basic geological framework of these cratons is known, comprehensive understanding of individual craton and their amalgamation history is still poorly known. The Dharwar craton exposes a wide oblique section of Precambrian continental crust formed during a late Archaean hot orogens. In the past 20 years the productive scientific cooperation between Indian and French scientific groups through IFCPAR has generated large multidisciplinary data base on the Dharwar craton. These fundamentally renewed our view of the geology of the Dharwar craton. Yet the relationship between the Dharwar craton with other Archaean provinces is poorly known and the craton still too rarely regarded as a global reference.

For the last three decades, no major international field workshop has been organized on the Dharwar craton. Realizing the strong need to bring global experts on Precambrian to Dharwar craton Prof. M.Jayananda and his colleagues have rightfully thought of organizing an international symposium and associated field workshop in the Dharwar craton. The two days symposium (2-3 Feb. 2011) and following field workshop (4-11 Feb. 2011) was jointly organized by the University of Delhi and the Geological Society of India.

The symposium was very well organized with inaugural ceremony held on the $2^{\text {nd }}$ of February 2011; the Chief Guests included Prof. Harsh Gupta, President, Geological Society of India, Dr. Shailesh Nayak, Secretary, Ministry of Earth Sciences, Government of India, Prof. S.K. Tandon, Former Pro-Vice-Chancellor, University of
Delhi. The inaugural ceremony was presided by Prof. Vivek Suneja, Pro-Vice-Chancellor, University of Delhi. Prof. Harsh Gupta emphasized the importance of understanding the deep structure of the continents in view of recent seismicity in stable continental regions.

An excellent abstract volume extending to 168 pages was published by the Geological Society of India covering the technical program of the symposium. There were 45 oral and 40 poster presentations. There were totally 12 invited keynote talks covering all the sessions. Bor-ming Jahn described the crustal evolution of Shandong province of North China craton with SHRIMP U-Pb zircon age data ranging between 3.2 to 2.5 $\mathrm{Ga}$. Ramakrishnan presented the advances in understanding the orogenic processes and suggested that the Sargur Group (3 to $3.3 \mathrm{Ga}$ ) $\mathrm{Ga}$ ) was involved in the subduction of oceanic plateau to produce TTG batholith (2.9 to 3.0 $\mathrm{Ga}$ ) of Peninsular gneiss covering the entire Dharwar craton. Michael Brown addressed an important topic of one-sided subduction that generates lower thermal gradients in the subduction channel and higher thermal gradients in the arc-back-arc or orogenic hinterland of the over-riding plate. He also deposited on a putative sialic basement $(>3.4$

opined that the change to one-sided subduction must have commenced locally in the Mesoarchean-Neoarchaean Eras and became global in the Paleo-Proterozoic, which was a landmark event in the Earth's history. Somnath Dasgupta reviewed the significant advances in the last two decades in understanding the nature of Proterozoic tectonothermal events in India from the Early to Paleo-Proterozoic Tectonothermal event ( 2500 to $1800 \mathrm{Ma}$ ) recorded in Southern Granulite Terrain (SGT), PaleoProterozoic to Early Meso-Proterozoic UHT event (Ca. 1800 to $1500 \mathrm{Ma}$ ) from the Central Indian Tectonic Zone (CITZ) ( 1.6 Ca) and correlated with the successive stages in the evolution of Columbia, Rodinia and Gondwana supercontinents. J.F. Moyen considered the range of existing Archaean granitoids, first from a global perspective as well as within the context of the Indian Dharwar craton and concluded that the existence of different granitoid types represent markers of distinct tectonic environments during the Archaean. Jaana Halla suggested that the geochemistry of Archaean granitoids would indicate how and when the modern style subduction processes began, and also pointed out that the slab-break off was responsible for the formation of sanukutoids.

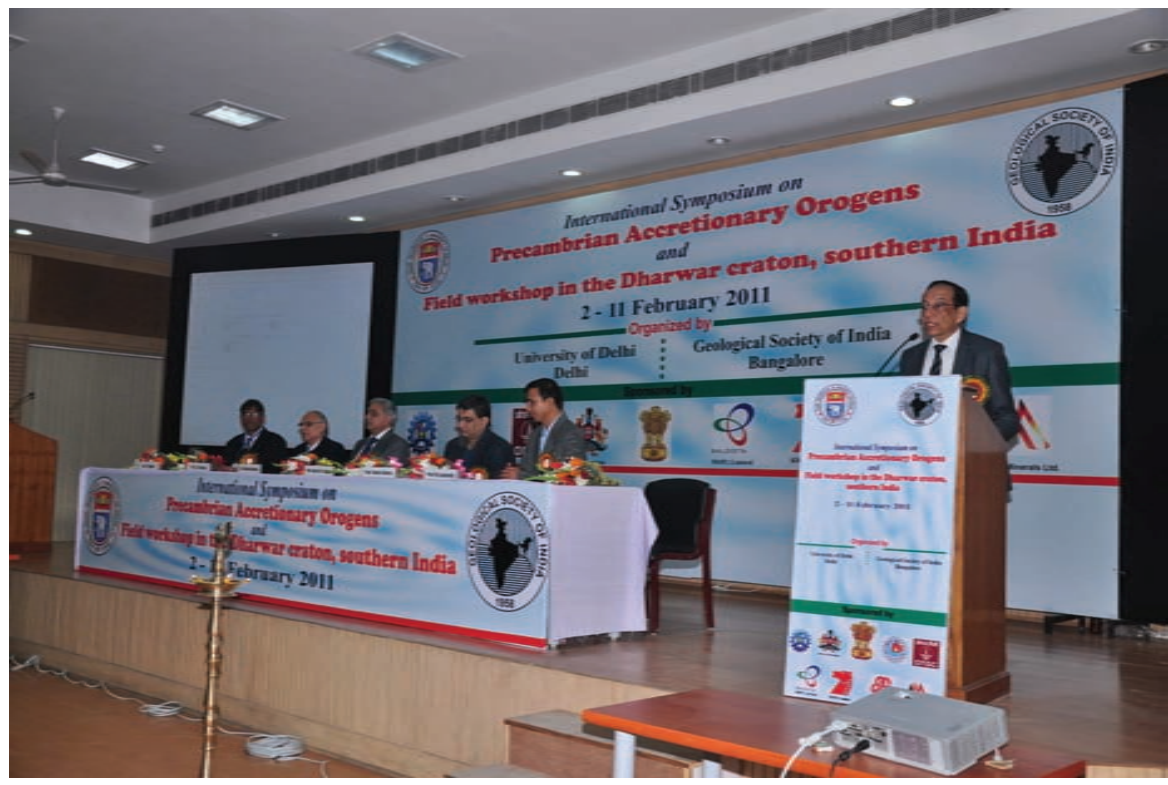

Fig.1. Prof. Harsh Gupta delivering inaugural address. 
Abhijit Basu emphasized the importance of robust geochronology, while reviewing the geology of Purana basins of India. The ages, on a regional scale, indicate: (i) the Purana basins are older by about 500 Ma than in the $20^{\text {th }}$ Century view; (ii) the extant $\mathrm{C}$-isotope marked; (iii) the real fossils identified in Purana are much older and may have had longer age-ranges; (iv) it remains to be tested if the putative interbasinal correlation can be achieved by stromatolite stratigraphy and (v) selected carbonate rocks from these basins are yet to be raided giant store house for information on the ocean-atmospheric interaction during Meso-Proterozoic. Robert Dall'Agnol described the evolution of granitoids from the Mesoarchaean Rio Maria granite greenstone terrane, eastern Amazonan craton, Brazil envisaging a tectonic model involving hot subduction underneath a thick oceanic plateau for the origin of different granitoid suites.

Bhaskar Rao presented recent results comprising zircon in-situ analysis aided by electron microprobe BSE/CL imaging, LAMICPMS U-Pb abundances for understanding the crust formation in western Dharwar craton. He concluded that ages and estimation of $\mathrm{U}, \mathrm{Th}, \mathrm{Zr}, \mathrm{Hf}, \mathrm{Y}, \mathrm{Yb}$ younger zircons with Dharwar craton indicate increasingly recycled crust that manifest in younger granites and granitic gneisses. Zorano Sergio de Souza, described five episodes of magma generation from 3.41 to $3.03 \mathrm{Ga}$, cycled each at $100 \mathrm{Ma}$, from the Sao Jose de Compestre Massif NE Brazil. He proposed a model of convergent stratigraphy of Purana basins is not timeages between 3.1 and $2.5 \mathrm{Ga}$ from the

tectonics and considered the generation of magmas by partial melting of hybridized lithospheric mantle, generating $\mathrm{Mg}$ - andesite that subsequently evolved by mantle and crustal pressure to form the differentiated series. Ewa Slaby addressed the issue of volatile elements in the petrogenesis of both mantle and crust derived magmatic rocks during the Archaean and suggested that some additional mechanisms like mixing, admixing and interaction could lead to large compositional diversity in terms of trace elements. Balaram emphasized the importance of ground and surface waters in geochemical exploration and in search of PGE minerals. He provided the list of mineralized areas of interest such as BaulaNuasahi ultramafic complex in Orissa, Madawara Igneous Complex in Uttar Pradesh and the Sittampudi-Bhavani layered maficultramafic complexes in Peninsular India.

In addition to the above keynote talks, there were several interesting presentations (both oral and poster) dealing with different aspects of geology and geophysics related to the thematic sessions. The program ended with a cultural program of delightful classical southern Indian Kuchipudi dance in the evening (Fig.2).

The field workshop was attended by about 50 scientists including senior scientists/ students from India and abroad. Unfortunately D. Chardon could not participate in the symposium and field workshop but field trip leader Prof. Jayananda showed us the entire results of Indo-French collaborative program in a carefully chosen crustal corridors of the Dharwar craton. The

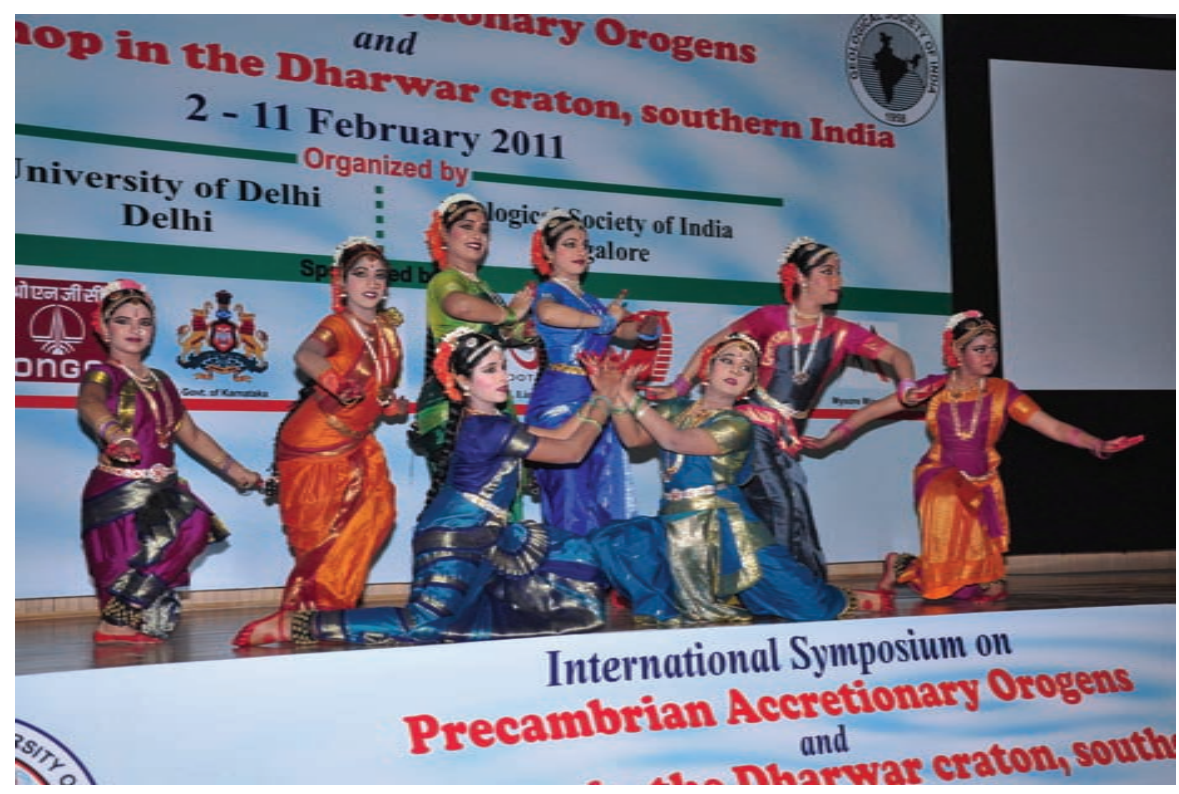

Fig.2. Artists performing southern Indian classical Kuchipudi dance. selected corridors covered large section of exposed Archaean crust passing through the boundary shear zone including different age provinces, lithological associations, structures and metamorphic grade. It was a good opportunity to see an exciting range of new data presented on the Dharwar craton, and allowed good interactions and discussions; for international visitors, it was also a good opportunity to discover the results generated by the Indian scientists; unfortunately a large part of their results is not accessible to the broader international community, and so it was a perfect opportunity to discover the amount of knowledge base that is accumulated in India. For the Indian participants, and especially the students or junior scientists, it allowed them to meet personally international scientific groups who worked and published on the Dharwar craton, and to interact with them. As the symposium was held in the University of Delhi, with most participants staying there, there was ample opportunity for all of us to meet, mingle and interact, from poster sessions to lunch/dinner a very pleasant programme of traditional Indian dances - all of them nicely organized and flawlessly ran by the convenors of the meeting.

Papers presented focussed on the Dharwar craton, with the addition of a few, more general presentations. A range of topics were discussed, including the origin of continents, the stratigraphy and igneous rocks of greenstone belts, the Archaean potassic granites (including TTGs), the Precambrian sedimentary basins, the structural and tectonic patterns of Precambrian accretionary orogens, mafic dyke swarms, and ore deposits associated to Precambrian areas.

In the concluding discussion session, several points of interests were raised. We discussed general geological issues regarding the tectonics of the Early Earth. All participants agreed on the fact that secular change is real, and that there are key differences between Archaean, Proterozoic and Phanerozoic systems; the nature and magnitude of these changes being, of course, the really controversial issue. There is definitely a need for a multi-disciplinary, undogmatic approach here, as one has to acknowledge, at the same time, the differences between Archaean and modern periods, but also their many similarities. Some key differences are the nature of igneous rocks (volcanic or plutonic); the metamorphic styles; the meaning of the greenstone belts associations; the structural, tectonic and 


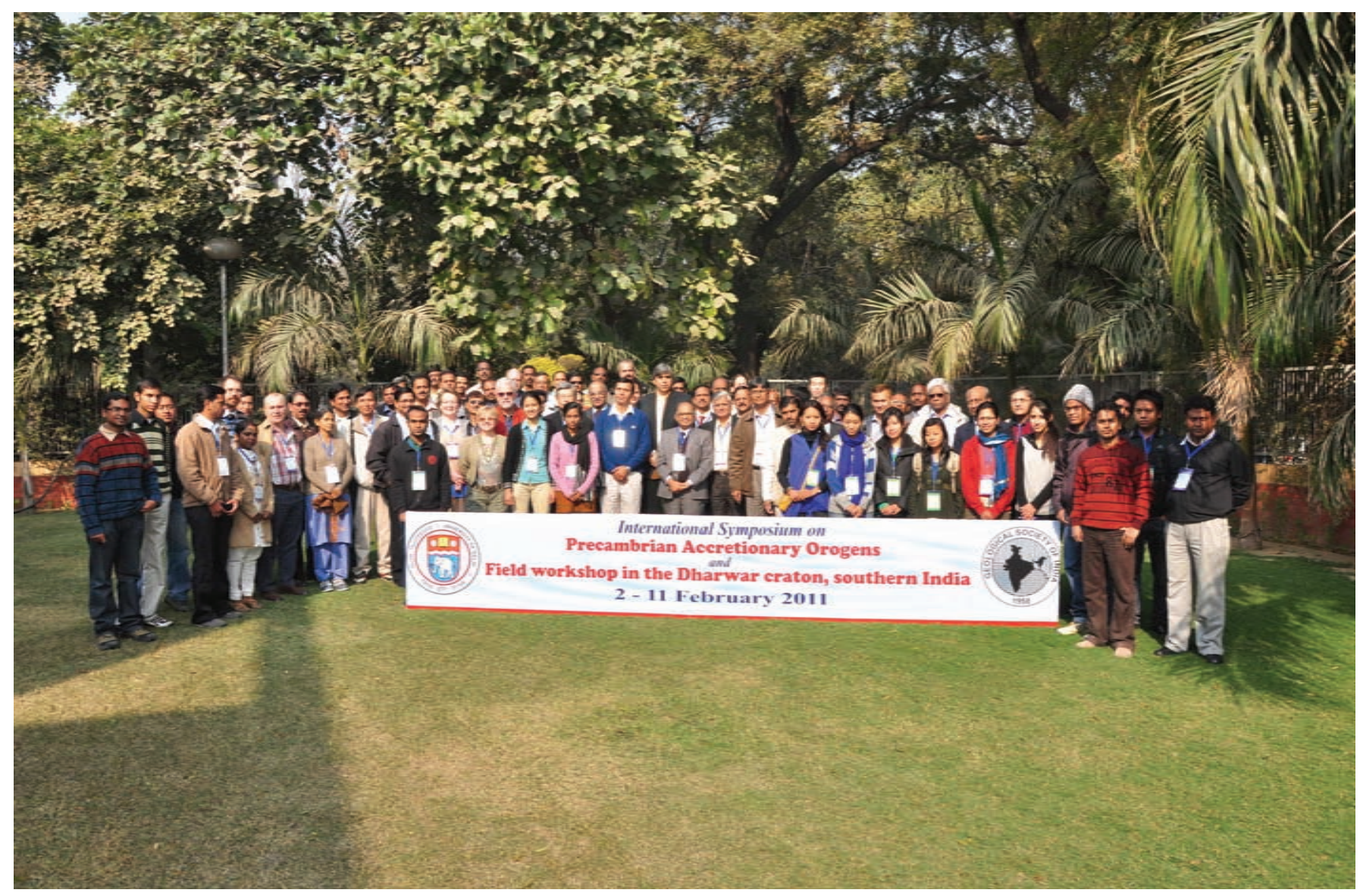

Fig.3. Group photo of the delegates participated in the symposium.

orogenic styles; the sedimentary basins (BIFs, for instance); the coupling between exogenic and endogenic processes; the mineralization and metallogenic processes, and the resulting mineral endowment of Precambrian terranes. Many general issues, central to the controversies surrounding Archaean geological processes, were discussed, including the modes of deformation of the Archaean crust; the meaning of Archaean metamorphic patterns; the ambiguity of geochemical signatures and the difficulty to relate them in simple terms to geodynamic environments.

Concerning the Dharwar craton itself, some of the questions that arose, and some suggestions for further work, including the need to better constrain the geochronological framework of Indian shield; the need to look into the metamorphic record using the modern tools now available (Holland and Powell, 2011; Kelsey and Powell, 2011); the lack of knowledge on the other Indian cratons (Bastar, Bundelkhand, Aravalli) and their relations. We know very little on the potential correlations between these cratons, nor on the accretionary processes that formed the Indian shield. In many parts of the world, paleomagnetic studies, as well as the investigation of mafic dyke swarms as a tool for inter-craton correlations, are commonly used (Bleeker, 2003); we know very little of these aspects in India.

Most participants agreed that good geochronological data, as well as a good geological framework (detail-scale mapping) are still largely missing in the Dharwar craton. While the limited facilities available in India for geochronology mean that international collaboration will be critical in constraining the timing of events, on the other hand geological mapping and detailed field studies is something that is more easily performed by Indian scientific groups. Projects aiming at the production of good litho-structural maps in different parts of the craton could very easily be performed with purely Indian resources, and would immensely contribute to our understanding of the geology of the craton. Indeed, good field studies are the basis onto which any good geological study is built - without a good understanding of the basic geology, the more advanced tools such as geochronology or isotopes are all but useless.

On Friday $4^{\text {th }}$, field participants flew to Bangalore to start on the second part of the conference - the field workshop in the
Dharwar craton. During that first day, we drove south-west to visit the internationally famous Kabbaldurga quarry, where amazing examples of interaction between melting, deformation and metamorphic overprint ("patchy charnockites") can be observed (Pichamuthu, 1960; Friend, 1981; Chardon and Jayananda, 2008); all the participants were delighted by the superb outcrop, and puzzled by the complex geology it displays; it is unfortunate that the heavy traffic in Bangalore meant that we arrived so late in Kabbaldurga, that we were unable to spend as long as we would have liked to spend on the outcrop.

On second day, the field workshop covered the crustal section covering Bangalore-Hassan corridor, examining the Closepet granite, during an unscheduled roadside stop where the outcrop displays superb examples of magma mingling in a plutonic environment (Jayananda et al., 1995; Moyen et al., 2001). We then returned to the planned itinerary, and visited 3.35 Ga old komatiites from the Banasandra belt (Jayananda et al., 2008) and 3.0 Ga high-K pluton at BellurNagamangala road before arriving in Hassan. Delightful interactions among the participants 
during dinner which was complemented by live classical Indian music.

The next day (Sunday $6^{\text {th }}$ February) was spent examining the Holenarsipur belt, and surrounding gneisses; participants discussed issues related to the stratigraphy of greenstones in the WDC (Swami Nath and Ramakrishnan, 1981; Peucat et al., 1995), especially the presence, or not, of rocks belonging to the Dharwar Supergroup in Holenarsipur; and the meaning and origin of the dome-and-keel pattern displayed by the belt and surrounding basement and granitic plutons (Bouhallier et al., 1993) (Fig.4).

On Monday ( $7^{\text {th }}$ February), we drove on the winding, scenic roads of the Western Ghats to visit the Kudremukh iron mine operated by KIOCL. On the way we examined exposures of TTG-quartzite/ conglomerate at the base of Sigegudda (Fig.5) for basement-cover relationship with well defined angular unconformity.

KIOCL had generously sponsored the symposium, and they were keen to interact with field workshop participants. We were welcomed by the chairman of the company, enjoyed lunch with the colleagues of KIOCL, and visited the mined areas. We had the opportunity to interact on the conflicting needs of conservation and minerals extraction, as Kudremukh mine is located in Kudremukh national park - and therefore, mining operations stopped five years ago due to environmental concerns, and despite the fact that some 600 million tons of low-grade ore remain unextracted in and below the mine. Finally the field party arrived at Chikmagalur during the night.

The whole of $8^{\text {th }}$ February was dedicated to Bababudan hills around the town of Chikmagalur. Detailed mapping of the belt by several groups (Chadwick et al., 1985;
Chardon et al., 1998; Chadwick et al., 2000) has been the basis for the production of very good data. We visited some key outcrops, discovered during regional mapping, again emphasising the need for good field work to constrain geological models. The day ended on top of the Mulaingiri Mountain (Fig.6), offering stunning views on the Bababudan hills jungle on one side and Chikmagalur and surroundings on the other side. All the outcrops are conveniently located within a few kilometres from the town, which made for a somewhat more relaxed day than the previous ones, allowing us to take it a bit easier, taste some locally-grown coffee and even enjoy the luxury of returning to our hotel before night!

On Wednesday, we left the Western Dharwar craton and crossed the boundary to the Eastern Dharwar. Again, the exposures we saw confirmed that detailed mapping is
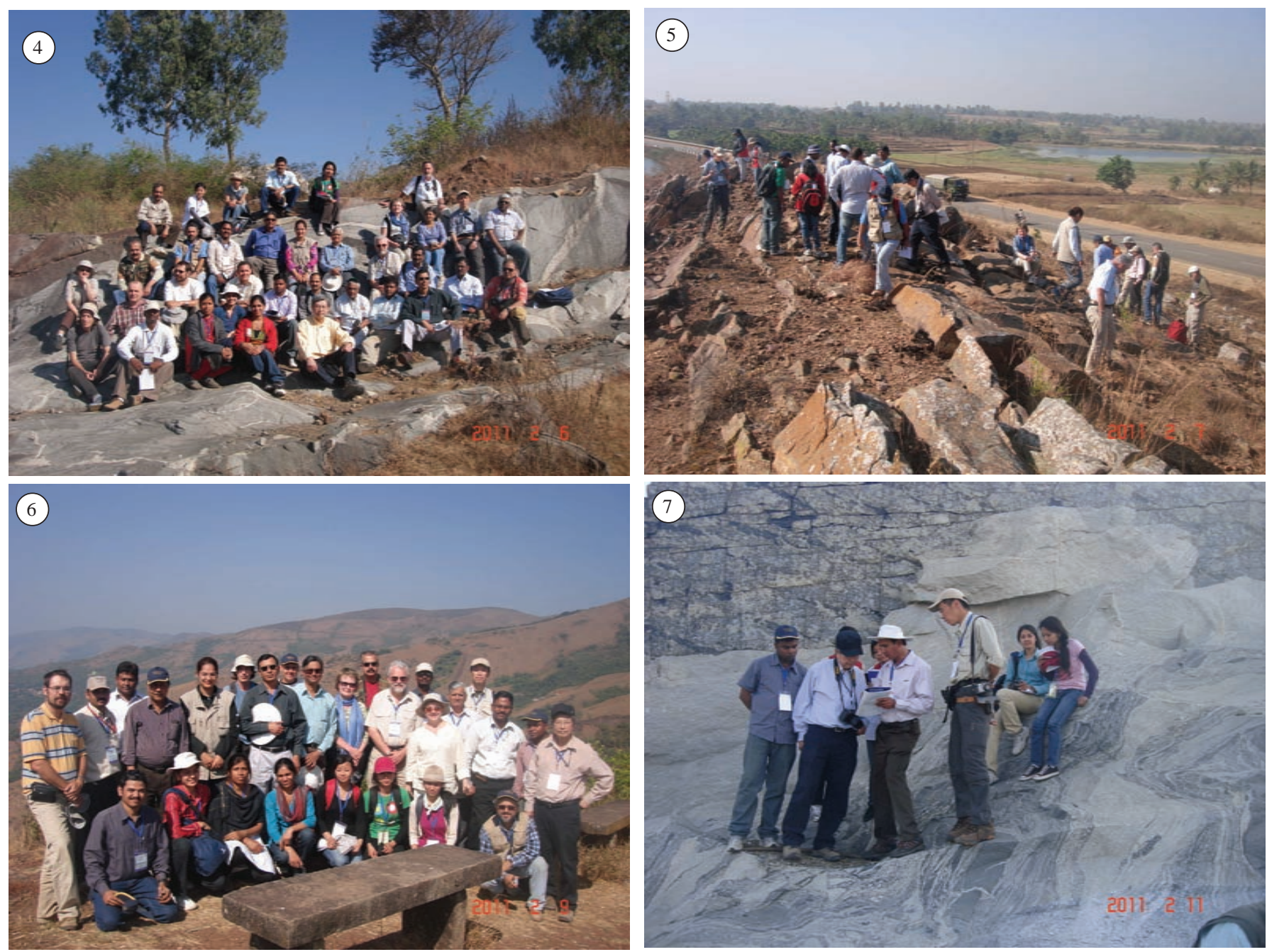

Figures 4-7. (4) Participants on the oldest dated 3.33 Ga Gorur gneiss. (5) Delegates discussing the basement cover-relationships on the quartzite/ conglomerate exposure at the base of Sigegudda hill. (6) Group photo of delegates on the BIFs of Mulaingiri Formation on Bababudan hills. (7) Participants discussing about the late Archaean (2.55-2.52 Ga ) juvenile magmatic accretion and reworking at well studied Madanapalli quarry exposure 
indeed vital to our understanding of the craton; the main outcrops we visited were discovered during regional mapping, and this work casts a new light on the EDC/WDC relations. Indeed, the meaning of this contact, its implications for the geological history of the craton as a whole, were the subject of long, sometimes heated discussions between the participants of the field trip, and we all agreed that this was indeed an absolutely critical area for our understanding of the late-Archaean evolution of the Dharwar craton. The field workshop group finally arrived at Bangalore during the night.

Finally, we drove to the delightful Horsley Hills hilltop resort, in SW Andhra Pradesh. This allowed us to see two outstanding outcrops exemplifying the ca. $2.55 \mathrm{Ga}$ plutonism in the EDC (Fig.7), and to explore the complex relation between successive granitic intrusions, melting and deformation in this area.

A concluding discussion session on top of Horsley Hills was an opportunity to touch on slightly philosophical issues. While the students and junior scientists on the trip expressed gratitude for the interesting discussions and interactions, the more senior people made a strong case for the need of a dis-respectful attitude towards established "truth" in science; models have to be challenged, opinions of the elders (even one's supervisor) must be questioned, and young people should not be afraid to voice their own opinions and debate published ideas.

This trip was an opportunity to realize how much work has been done in the Dharwar craton in the past 10 or 20 years; but also, unfortunately, how little of it is known outside of India. Our understanding of Dharwar geology has greatly progressed; we now have a reasonable framework for the geological evolution of the craton, the meaning of the differences between its two portions, the distribution of ages and lithologies in both halves, the late-Archaean strain patterns. Participants agreed that the general geology of the craton suggests a collision (of some sort) between a hard, cold, Western Dharwar and a soft, hotter Eastern Dharwar craton, at ca. $2.5 \mathrm{Ga}$; although the strain pattern records no evidence for lateral accretion between the two regions, the age differences do require some horizontal mobility, probably just before $2.5 \mathrm{Ga}$. Some interesting geological questions arose: are there any metamorphic records of the "collision" between East and West Dharwar craton? What is the meaning of the very large area of ca. $2.5 \mathrm{Ga}$ juvenile magmatism in the Eastern Dharwar craton: it is, by far, too wide to represent a true magmatic arc, and lacks the age zonation that should be expected; yet its chemistry is essentially calc-alkaline and "arc like". If the observed strain field is unrelated to the lateral accretion of crustal blocks, are there any records for this process, other than the age differences between parts of the craton? How much difference is there, within the EDC, between the region East and West of Kolar: West of Kolar, there is an old inheritance (up to $3.1 \mathrm{Ga}$ ) that seems to be lacking East of it. In the Western Dharwar craton, how much of the observed structures and metamorphic patterns are related to the ca. 2.5 Ga deformation, and how much are older (midArchaean)? Clearly, all this questions have to be addressed by a combination of careful field work, supplemented by detailed petrological, geochemical and geochronological studies.

Last, but not least, the symposium and associated field workshop was excellent and meticulously organized. Finally, we hope that the field workshop has provided new stimulus and insights to address major scientific issues of Precambrian accretionary orogens and initiate new international scientific cooperation in understanding the geodynamic processes of primitive Earth keeping the Dharwar craton as a central theme.

This symposium was a very rewarding experience for all participants.

\section{Jean-François Moyen}

Laboratoire Transferts Lithposphèriques, UMR 6524 "Magmas et Volcans", CNRS, Université Jean-Monnet,

\section{3 rue du Docteur Michelon 42023}

Saint-Etienne, France

E-mail: Jean.francois.moyen@univ-stetienne.fr

\section{References}

Bleeker, W., 2003. The late Archean record: a puzzle in ca. 35 pieces. Lithos, 71(2-4): 99134.

Bouhallier, H., Choukroune, P. and Ballèvre, M., 1993. Diapirism, bulk homogeneous shortening and transcurrent shearing in the Archaean Dharwar craton : the Holenarsipur area, Southern India. Precambrian Research, 63: 43-58.

Chadwick, B., Ramakrishnan, M. and Viswanatha, M., 1985. Bababudan-a late Archaean intracratonic volcano-sedimentary basin, Karnataka, Southern India. I: Stratigraphy and basin develop-ment $=$ Bababudan - un bassin volcano-sédimentaire intracratonique de l'Archéen supérieur, Karnataka, Inde du Sud.
I: stratigraphie et évolution du bassin. Journal of the Geological Society of India, 26(11): 769-801.

Chadwick, B., Vasudev, V.N. and Hegde, G.V., 2000. The Dharwar Craton, southern India, interpreted as the result of late Archaean oblique convergence. Precambrian Research, 99: 91-111.

Chardon, D. and Jayananda, M., 2008. Threedimensional field perspective on deformation, flow, and growth of the lower continental crust (Dharwar craton, India). Tectonics, 27(1)

Chardon, D., Jayananda, M., Chetty, T.R.K. and Peucat, J.J., 2008. Precambrian continental strain and shear zone patterns: South Indian case. Journal of Geophysical Research-Solid Earth, 113(B8)

Chardon, D.H., Choukroune, P. and Jayananda, M., 1998. Sinking of the Dharwar Basin (South India); implications for Archaean tectonics. Precambrian Research, 91: 15-39.

Friend, C., 1981. Charnockite and granite formation and influx of $\mathrm{CO}_{2}$ at Kabbaldurga. Nature, 294: 550-552.

Holland, T.J.B. and Powell, R., 2011. An improved and extended internally consistent thermodynamic dataset for phases of petrological interest, involving a new equation of state for solids. Journal of Metamorphic Geology, in press.

Jayananda, M., Martin, H., Peucat, J.J. and Mahabaleswar, B., 1995. Late Archean CrustMantle Interactions - Geochemistry of LreeEnriched Mantle Derived Magmas - Example of the Closepet Batholith, Southern India. Contributions to Mineralogy and Petrology, 119(2-3): 314-329

Jayananda, M., Kano, T., Peucat, J.J. and Channabasappa, S., 2008. 3.35 Ga komatiite volcanism in the western Dharwar craton, southern India: Constraints from $\mathrm{Nd}$ isotopes and whole-rock geochemistry. Precambrian Research, 162(1-2): 160-179.

Kelsey, D. and Powell, R., 2011. Progress in linking accessory mineral growth and breakdown to major mineral evolution in metamorphic rocks: a thermodynamic approach in the $\mathrm{Na}_{2} \mathrm{O}$ $\mathrm{CaO} \mathrm{K}_{2} \mathrm{O} \mathrm{FeO} \mathrm{MgO} \mathrm{Al} \mathrm{O}_{3} \mathrm{SiO}_{2} \mathrm{H}_{2} \mathrm{O} \mathrm{TiO}_{2}$ $\mathrm{ZrO}_{2}$ system. Journal of Metamorphic Geology, in press.

Moyen, J.F., Martin, H. and Jayananda, M., 2001. Multi-element geochemical modelling of crust-mantle interactions during late-Archaean crustal growth: the Closepet granite (South India). Precambrian Res., 112(1-2): 87-105.

Peucat, J.J., Bouhallier, H., Fanning, C.M. and Jayananda, M., 1995. Age of the Holenarsipur greenstone belt, relationshis with the surrounding gneisses (Karnataka, South India). Journal of Geology, 103: 701-710.

Pichamuthu, C., 1960. Charnockite in the making. Nature, 188: 135-136.

Swami Nath, J. and Ramakrishnan, M., 1981. Early Precambrian supracrustals of southern Karnataka. Mem. Geol. Surv. India, 112: 1350 . 